\title{
Primary Systemic Therapy in Breast Cancer
}

\author{
Uwe-Jochen Göhring ${ }^{a^{*}}$ Erich Solomayer ${ }^{b^{*}}$ \\ a Abteilung für Gynäkologie und Geburtshilfe, Johanniter-Krankenhaus, Evangelische Kliniken Bonn, \\ b Universitäts-Frauenklinik Tübingen, Germany
}

\section{Key Words}

Systemic therapy, primary - Neoadjuvant therapy · Breast cancer - AGO

\section{Summary}

Initially, only patients with inflammatory or inoperable locally advanced breast cancer were candidates for preoperative chemotherapy. The aim was to downstage tumors to make a surgical procedure feasible. Currently, preoperative therapy is administrated to an increasing number of patients. The monitoring of the treatment serves as an in vivo test. The prognosis of patients is the same as with adjuvant therapy. The rate of pathologically complete remission is increasing with more experience with the neoadjuvant treatment. New drugs contributed to the development of such treatment strategies.

\footnotetext{
*As members of the Breast Commission, part of the AGO (Working Group Gynecologic Oncology, German Society of Obstetrics and Gynecology)
}

\author{
Schlüsselwörter \\ Systemische Therapie, primäre · Neoadjuvante Therapie · \\ Mammakarzinom · AGO
}

\section{Zusammenfassung}

Die präoperative Therapie wurde ursprünglich zur Besserung der Operabilität eingesetzt. Bei inoperablen Tumoren konnte eine chirurgische Intervention angeschlossen werden, und bei initial sehr großen Karzinomen konnte durch den Einsatz der präoperativen Therapie eine brusterhaltende Therapie durchgeführt werden. Heutzutage wird die präoperative Therapie immer häufiger eingesetzt. Neben der Erhöhung der Rate brusterhaltender Operationen kann das Therapieansprechen wie ein in-vivo Sensibilitätstest gewertet werden. Die Prognose der Patientinnen ist mindestens so gut wie nach adjuvanter Therapie. Die Rate an pathologisch kompletten Remissionen erhöhte sich mit zunehmender Erfahrung mit dieser Therapiemodalität. Die Einführung neuer Medikamente führt auch zu einer Verbesserung der Strategiekonzepte beim Mammakarzinom.

The cornerstone for the use of primary chemotherapy for the treatment of breast cancer has been laid in the early 1970s. The NSABP-B18 study compared an anthracycline regimen $(A C \times 4, q 3 w)$ that was given either before or after surgical therapy. The study originally intended to show the superiority of one of the regimens, but long-term results demonstrated identical survival rates of the two groups [1]. Further clinical studies confirmed a comparable efficacy of both neoadjuvant

\begin{tabular}{ll}
\hline KARGER & ( 2006 S. Karger GmbH, Freiburg \\
Fax +497614520714 & Accessible online at: \\
$\begin{array}{l}\text { E-mail Information@Karger.de } \\
\text { www.karger.com }\end{array}$ & www.karger.com/brc
\end{tabular}


and adjuvant chemotherapy protocols. Protocols that need to be mentioned besides the NSABP-B18 study $(\mathrm{AC} \times 4, \mathrm{n}=$ $1523)$ are the French study $(\mathrm{FAC} \times 4, \mathrm{n}=390)$, the EORTC $(\mathrm{FEC} \times 4, \mathrm{n}=698)$, the ECTO (AT-CMF, $\mathrm{n}=13$ ) and the NSABP-B27- $(\mathrm{FEC} \times 4, \mathrm{n}=2411)$ study [2-5]. In their metaanalysis Mauri et al. [6] summarized 9 important randomized studies and outlined advantages and disadvantages of both preoperative and postoperative chemotherapy regimes. No significant differences concerning survival $(\mathrm{RR}=1.00,95 \%$ confidence interval $(\mathrm{CI})=0.90-1.12)$, tumor progression $(\mathrm{RR}$ $=0.99,95 \% \mathrm{CI}=0.91-1.07)$ or development of metastases ( $\mathrm{RR}=0.94,95 \% \mathrm{CI}=0.83-1.06)$ could be seen. Primary systemic therapy, however, was associated with an increased rate of local relapses $(\mathrm{RR}=1.53,95 \% \mathrm{CI}=1.11-2.1)$. The rate of clinical complete remission varied between 7 and $65 \%(\mathrm{p}<$ 0.001 ), pathological complete remissions were described between 4 and $29 \%(p<0.001)$. Response to therapy described by pathological complete remission (pCR) in breast and/or axilla correlates with better survival [1, 6-9].

Data confirming advantages of neoadjuvant treatment for patients with primary inoperable disease have been published, demonstrating an increased rate of breast-conserving surgery for these patients [1-3, 5, 10-13]. An additional advantage of neoadjuvant chemotherapy is rooted in the possibility of measuring clinical response at an early stage of disease - also leading to a major psychological advantage for the patient. Switching chemotherapeutic agents towards non cross-resistant regimes is possible, allowing fast evaluation of new drugs and/or therapeutic modalities [1, 14].

Primary inoperable invasive carcinomas (LOE 1c / A, AGO ++ ), inflammatory breast cancer ( $\mathrm{LOE} 1 \mathrm{~b} / \mathrm{B}, \mathrm{AGO}++)$ and established indications for the need of postoperative chemotherapeutic treatments (LOE $1 \mathrm{~b} / \mathrm{A}, \mathrm{AGO}+$ ) represent indications for primary systemic therapies [1-2, 10-15] (fig. 1). If a priori any contraindication against breast conserving therapy can be determined (e.g. multicentric carcinoma, wide areas of microcalcifications or in case radiotherapy is not feasible, each LOE V/D, AGO ++), then primary systemic therapy can not be used in the intention to conserve the breast in the following surgical procedure [16]. Chemotherapeutic combinations described in established clinical studies should be applied when determining therapeutic regimes, referring mainly to AC-D (LOE 2b / A, AGO +), DAC (LOE 2b /B, $\mathrm{AGO}+$ ), and AP-CMF (2b/B, AGO +) [4-5, 13, 17] (fig. 2).

In HER2/neu-positive tumors trastuzumab has been employed as primary systemic therapy [18-20]. In 2005 Buzdar and coworkers [18] were able to show significantly increased pathological complete remission rates when trastuzumab was added to a regimen with paclitaxel $\times 4$, $\mathrm{q} 3 \mathrm{w}$ followed by FEC $\times 4$ q3w (25\% vs. $66.7 \%)$. Already after 32 patients had been randomized, the Data Monitoring Committee stopped the study. At present, trastuzumab is used in HER2/neu-positive patients undergoing primary systemic therapy in clinical study conditions (e.g. GEPARQUATTRO, HEDON). The out-of-

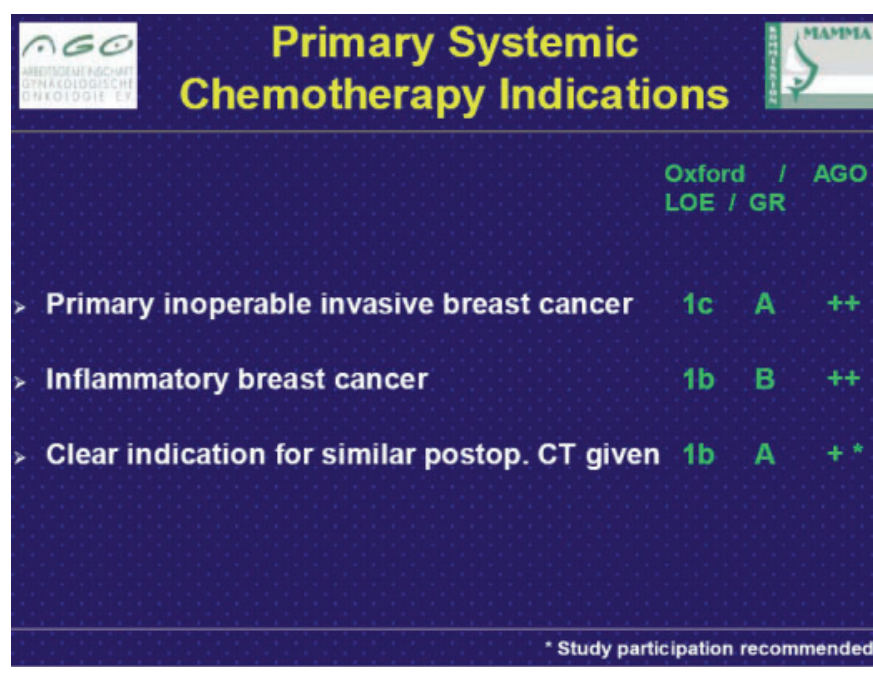

Fig. 1. Indications for primary systemic chemotherapy.

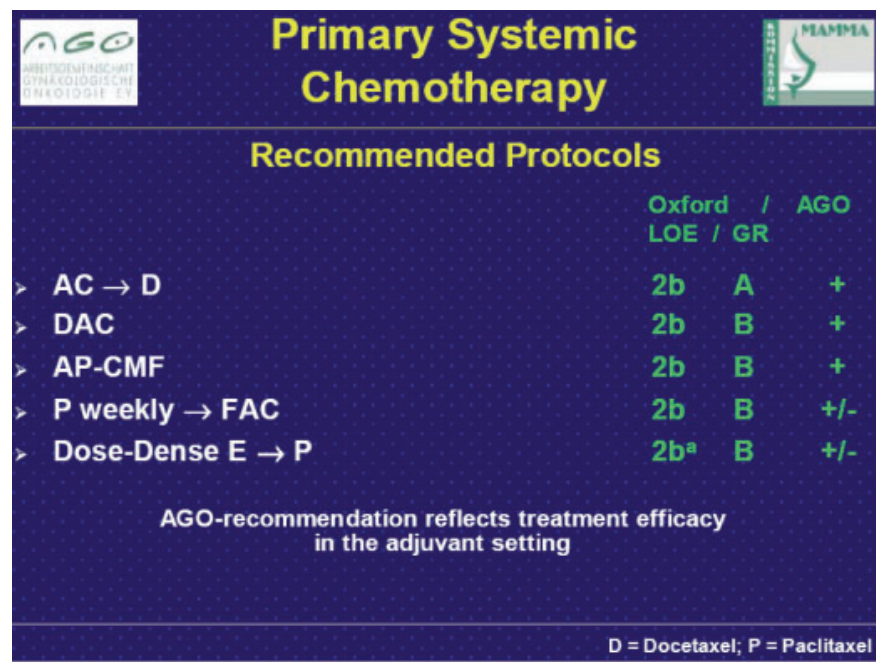

Fig. 2. Recommended protocols for primary systemic chemotherapy.

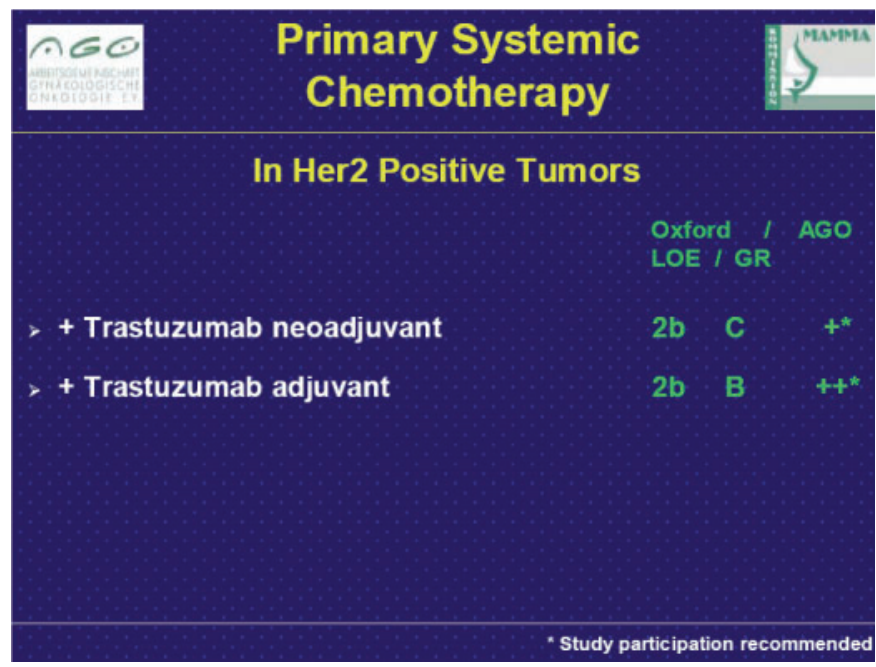

Fig. 3. Recommendations for primary systemic therapy in HER2-positive tumors.

study use of trastuzumab is not part of clinical routine yet (fig. 3). 


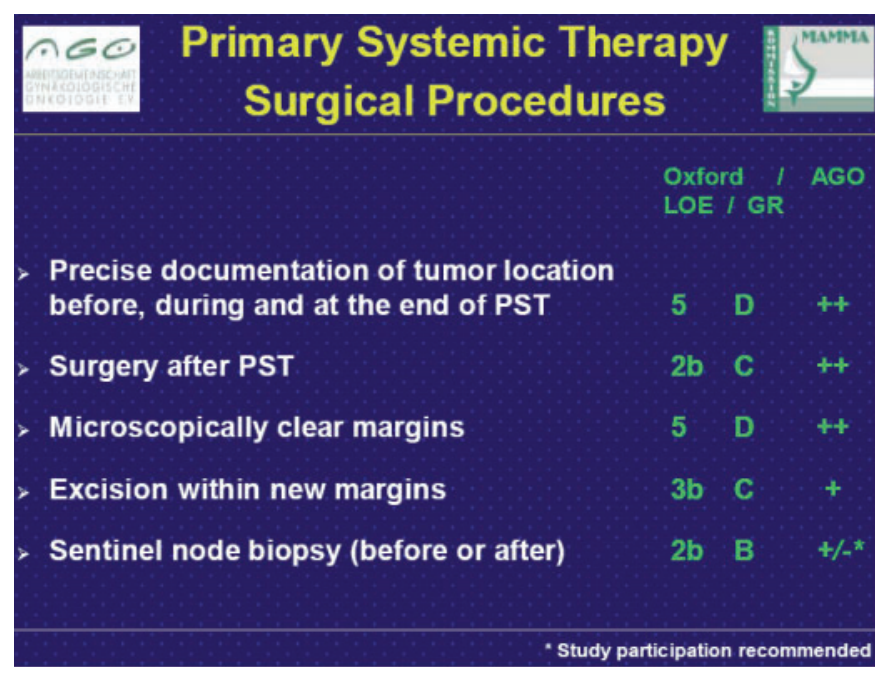

Fig. 4. Recommendations for surgical procedures after primary systemic therapy.

Compared to primary surgical therapy the implementation of primary systemic therapy holds a number of risks (fig. 4). Localization of the tumor needs to be defined and precisely described, response to therapy needs to be monitored at regular intervals (LOE $5 / \mathrm{D}, \mathrm{AGO}++$ ). Surgery after PST is obligatory (LOE $2 \mathrm{~b} / \mathrm{C}, \mathrm{AGO}++$ ) and should be scheduled about 2-4 weeks after the last cycle of chemotherapy and after passing the leucopenic nadir (LEO 4/ C, AGO ++). A reliable/assured microscopic complete resection must be reached (LOE $5 / \mathrm{D}, \mathrm{AGO}++$ ). If this condition is met, excision may be conducted in the new ( = after PST) tumor boundaries (LOE 3b/ $\mathrm{C}, \mathrm{AGO}++)[4,14,21]$. No stringent data exist concerning sentinel node biopsy before or after PST. The NSABP-B27 study examined this issue systematically and showed results according to the established approach. Sentinel node biopsy in combination with PST should - at present - be limited to clinical studies (LOE 2b / B, AGO +/-) [5, 14, 22].

Indication for radiation therapy needs to be determined before PST according to generally valid standards. Therefore, radiation after mastectomy is indicated when a patient shows positive lymph nodes or T3/T4 tumors (cN+, cT3/4a-d). Radiation therapy should begin 2-3 weeks after surgery (LOE $2 b$ / $\mathrm{B}, \mathrm{AGO}++)$.

In case of no response to primary systemic therapy, i.e. no change in the tumor evaluation, chemotherapy should be completed and surgery should follow as it has been originally

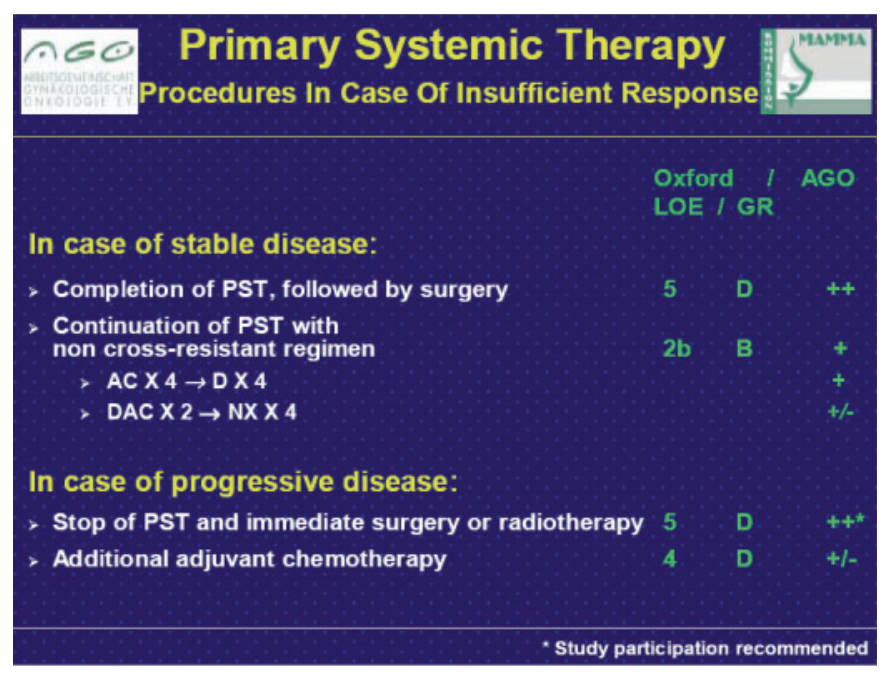

Fig. 5. Recommendations for primary systemic therapy in case of insufficient response.

planned (LOE 5 / D, AGO ++). Alternatively, therapy can be switched to a non cross resistant regime (LOE $2 \mathrm{~b} / \mathrm{B}$ : $\mathrm{AC} \times 4$ switch to $\mathrm{D} \times 4, \mathrm{AGO}+$; $\mathrm{DAC} \times 2$ switch to $\mathrm{NX} \times 4, \mathrm{AGO}+/-$ ). If the disease is progressive under therapy, PST has to be abandoned and surgery or radiotherapy must follow immediately (LOE 5 / D, AGO ++). Concerning adoption of an additional adjuvant therapy no reliable data exist (LOE $4 / \mathrm{D}$, AGO +/-) [13-14, 23] (fig. 5).

At present, no long-term results exist comparing primary systemic to primary endocrine therapy. Ideal duration of therapy is unclear. This leads to only general recommendations: Primary endocrine therapy is indicated for postmenopausal patients with hormone sensitive breast tumors who are not able to undergo chemotherapy or who show inoperable disease (LOE 5 / $\mathrm{D}, \mathrm{AGO}+)$. Study results demonstrate that the use of aromatase inhibitors ( $>3$ months instead of tamoxifen) leads to an increased rate of breast conserving therapy (LOE 1b / B, AGO $+/-)$. A concurrent chemo-endocrine therapeutic regime in primary application is obsolete (LOE $1 \mathrm{~b} / \mathrm{A}, \mathrm{AGO}--)$ [24-29]. Present review articles $[14,30]$ look intelligently into the topic 'primary systemic therapy' and confirm it as a standard therapeutic option in the treatment of primary breast cancer. An increased rate of breast conserving therapy is classified as an essential clinical advantage. Therefore, pathological complete remission is considered a surrogate marker for the efficacy of chemotherapeutic regimens.

\section{References}

1 Fisher B, Bryant J, Wolmark N, Mamounas E, Brown A, Fisher ER, Wickerham DL, Begovic M, DeCillis A, Robidoux A, Margolese RG, Cruz AB Jr, Hoehn JL, Lees AW, Dimitrov NV, Bear HD Effect of preoperative chemotherapy on the outcome of women with operable breast cancer. J Clin Oncol 1998;16(8):2672-85.
2 Scholl SM, Pierga JY, Asselain B, Beuzeboc P, Dorval T, Garcia-Giralt E, Jouve M, Palangie T, Remvikos Y, Durand JC: Breast tumour response to primary chemotherapy predicts local and distant control as well as survival. Eur J Cancer 1995; 31A(12):1969-75.
3 Semiglazov VF, Topuzov EE, Bavli JL, Moiseyenko VM, Ivanova OA, Seleznev IK, Orlov AA, Barash NY, Golubeva OM, Chepic OF: Primary (neoadjuvant) chemotherapy and radiotherapy compared with primary radiotherapy alone in stage IIb-IIIa breast cancer. Ann Oncol 1994;5(7):591-5. 
4 Mamounas EP, Brown A, Anderson S, Smith R, Julian T, Miller B, Bear HD, Caldwell CB, Walker AP, Mikkelson WM, Stauffer JS, Robidoux A, Theoret H, Soran A, Fisher B, Wickerham DL, Wolmark N: Sentinel node biopsy after neoadjuvant chemotherapy in breast cancer: results from National Surgical Adjuvant Breast and Bowel Project Protocol B-27. J Clin Oncol 2005;23(12):2694-702.

5 Gianni L, Baselga J, Eiermann W, Guillem Porta V, Semiglazov V, Lluch A, Zambetti M, Sabadell D, Raab G, Llombart Cussac A, Bozhok A, MartinezAgullo A, Greco M, Byakhov M, Lopez Lopez JJ, Mansutti M, Valagussa P, Bonadonna G; European Cooperative Trial in Operable Breast Cancer Study Group: Feasibility and tolerability of sequential doxorubicin/paclitaxel followed by cyclophosphamide, methotrexate, and fluorouracil and its effects on tumor response as preoperative therapy. Clin Cancer Res 2005;11:8715-21.

6 Mauri D, Pavlidis N, Ioannidis JP: Neoadjuvant versus adjuvant systemic treatment in breast cancer: a meta-analysis. J Natl Cancer Inst 2005;97(3): 188-94.

7 Feldman LD, Hortobagyi GN, Buzdar AU, Ames FC, Blumenschein GR: Pathological assessment of response to induction chemotherapy in breast cancer. Cancer Res 986;46(5):2578-81.

8 Kuerer HM, Sahin AA, Hunt KK, Newman LA, Breslin TM, Ames FC, Ross MI, Buzdar AU, Hortobagyi GN, Singletary SE: Incidence and impact of documented eradication of breast cancer axillary lymph node metastases before surgery in patients treated with neoadjuvant chemotherapy. Ann Surg 1999;230(1):72-8.

$\checkmark 9$ Pierga JY, Mouret E, Dieras V, Laurence V, Beuzeboc P, Dorval T, Palangie T, Jouve M, VincentSalomon A, Scholl S, Extra JM, Asselain B, Pouillart P: Prognostic value of persistent node involvement after neoadjuvant chemotherapy in patients with operable breast cancer. Br J Cancer 2000; 83(11):1480-7.

10 Bonadonna G, Veronesi U, Brambilla C, Ferrari L, Luini A, Greco M, Bartoli C, Coopmans de Yoldi G, Zucali R, Rilke F: Primary chemotherapy to avoid mastectomy in tumors with diameters of three centimeters or more. J Natl Cancer Inst 1990; 82:1539-45.

11 Calais G, Berger C, Descamps P, Chapet S, Reynaud-Bougnoux A, Body G, Bougnoux P, Lansac J, Le Floch O: Conservative treatment feasibility with induction chemotherapy, surgery, and radiotherapy for patients with breast carcinoma larger than $3 \mathrm{~cm}$. Cancer 1994;74:1283-8.

12 Chollet P, Charrier S, Brain E, Cure H, van Praagh I, Feillel V, de Latour M, Dauplat J, Misset JL, Ferriere JP: Clinical and pathological response to primary chemotherapy in operable breast cancer. Eur J Cancer 1997:33:862-6.
13 von Minckwitz G, Raab G, Caputo A, Schutte M, Hilfrich J, Blohmer JU, Gerber B, Costa SD, Merkle E, Eidtmann H, Lampe D, Jackisch C, du Bois A, Kaufmann M: Doxorubicin with cyclophosphamide followed by docetaxel every 21 days compared with doxorubicin and docetaxel every 14 days as preoperative treatment in operable breast cancer: the GEPARDUO study of the German Breast Group. J Clin Oncol 2005;23:2676-85.

14 Kaufmann M, Hortobagyi GN, Goldhirsch A, Scholl S, Makris A, Valagussa P, Blohmer JU, Eiermann W, Jackesz R, Jonat W, Lebeau A, Loibl S, Miller W, Seeber S, Semiglazov V, Smith R, Souchon R, Stearns V, Untch M, von Minckwitz G: Recommendations from an international expert panel on the use of neoadjuvant (primary) systemic treatment of operable breast cancer: an update. J Clin Oncol 2006;24(12):1940-9.

15 Mano MS, Awada A: Primary chemotherapy for breast cancer: the evidence and the future. Ann Oncol 2004;15:1161-71.

16 Singletary SE, McNeese MD, Hortobagyi GN: Feasibility of breast-conservation surgery after induction chemotherapy for locally advanced breast carcinoma. Cancer 1992;69:2849-52.

17 von Minckwitz G, Blohmer JU, Loehr A, Raab G, Eidtmann H, Hilfrich J, Gerber B, Huober J, Costa SD, Jackisch C, Loibl S, Schickling O, Zuna I, Kaufmann M: Comparison of docetaxel/doxorubicin/ cyclophosphamide (TAC) versus vinorelbine/ capecitabine $(\mathrm{NX})$ in patients non-responding to 2 cycles of neoadjuvant TAC chemotherapy first results of the phase III GEPARTRIO-Study by the German Breast Group. SABCS 2005; Abstr 38.

18 Buzdar AU, Ibrahim NK, Francis D, Booser DJ, Thomas ES, Theriault RL, Pusztai L, Green MC, Arun BK, Giordano SH, Cristofanilli M, Frye DK, Smith TL, Hunt KK, Singletary SE, Sahin AA, Ewer MS, Buchholz TA, Berry D, Hortobagyi GN: Significantly higher pathologic complete remission rate after neoadjuvant therapy with trastuzumab, paclitaxel, and epirubicin chemotherapy: results of a randomized trial in human epidermal growth factor receptor 2-positive operable breast cancer. J Clin Oncol 2005;23(16):3676-85.

19 Mohsin SK, Weiss HL, Gutierrez MC, Chamness GC, Schiff R, Digiovanna MP, Wang CX, Hilsenbeck SG, Osborne CK, Allred DC, Elledge R, Chang JC: Neoadjuvant trastuzumab induces apoptosis in primary breast cancers. J Clin Oncol 2005; 23(11):2460-8.

20 Untch M, Stoeckl D, Konecny G, Kreienberg R, Thommsen C, Camara O, Moebus V, Kuehn T, DuBois A, Lueck HJ, Gitsch G, Fasching P: A multicenter phase II study of preoperative epirubicin, cyclophosphamide (EC) followed by paclitaxel (P) plus trastuzumab $(\mathrm{T})$ in Her2 positive primary breast cancer. SABCS 2005; Abstr 1064.

21 Kuerer HM, Singletary SE, Buzdar AU, Ames FC, Valero V, Buchholz TA, Ross MI, Pusztai L, Hortobagyi GN, Hunt KK: Surgical conservation planning after neoadjuvant chemotherapy for stage II and operable stage III breast carcinoma. Am J Surg 2001;182(6):601-8.
22 van Rijk MC, Nieweg OE, Rutgers EJ, Oldenburg HS, Olmos RV, Hoefnagel CA, Kroon BB: Sentinel node biopsy before neoadjuvant chemotherapy spares breast cancer patients axillary lymph node dissection. Ann Surg Oncol 2006;13:475-9.

23 Smith IC, Heys SD, Hutcheon AW, Miller ID, Payne S, Gilbert FJ, Ah-See AK, Eremin O, Walker LG, Sarkar TK, Eggleton SP, Ogston KN: Neoadjuvant chemotherapy in breast cancer: significantly enhanced response with docetaxel. J Clin Oncol 2002;20(6):1456-66

24 Eiermann W, Paepke S, Appfelstaedt J, LlombartCussac A, Eremin J, Vinholes J, Mauriac L, Ellis M, Lassus M, Chaudri-Ross HA, Dugan M, Borgs M: Preoperative treatment of postmenopausal breast cancer patients with letrozole: A randomized double-blind multicenter study. Ann Oncol 2001; 12(11):1527-32.

25 Ellis MJ, Coop A, Singh B, Mauriac L, LlombertCussac A, Janicke F, Miller WR, Evans DB, Dugan M, Brady C, Quebe-Fehling E, Borgs M: Letrozole is more effective neoadjuvant endocrine therapy than tamoxifen for ErbB-1- and/or ErbB-2-positive, estrogen receptor-positive primary breast cancer: evidence from a phase III randomized trial. J Clin Oncol 2001;19:3808-16.

26 von Minckwitz G, Costa SD, Raab G, Blohmer JU, Eidtmann H, Hilfrich J, Merkle E, Jackisch C, Gademann G, Tulusan AH, Eiermann W, Graf E, Kaufmann M: Dose-dense doxorubicin, docetaxel, and granulocyte colony-stimulating factor support with or without tamoxifen as preoperative therapy in patients with operable carcinoma of the breast: a randomized, controlled, open phase IIb study. J Clin Oncol 2001;19:3506-15.

27 Smith IE, Dowsett M, Ebbs SR, Dixon JM, Skene A, Blohmer JU, Ashley SE, Francis S, Boeddinghaus I, Walsh G: Neoadjuvant treatment of postmenopausal breast cancer with anastrozole, tamoxifen, or both in combination: the Immediate Preoperative Anastrozole, Tamoxifen, or Combined with Tamoxifen (IMPACT) multicenter double-blind randomized trial. J Clin Oncol 2005;23:5108- 16.

28 Cataliotti L, Buzdar AU, Noguchi S, Bines J, Takatsuka Y, Petrakova K, Dube P,Tosello de Oliveira C: Comparison of anastrozole versus tamoxifen as preoperative therapy in postmenopausal women with hormone receptor-positive breast cancer: the pre-operative 'Arimidex' compared to Tamoxifen (PROACT) trial. Cancer 2006;106:2095-103.

29 Hind D, Wyld L, Beverley CB, Reed MW: Surgery versus primary endocrine therapy for operable primary breast cancer in elderly women (70 years plus).Cochrane Database Syst Rev 2006;(1): CD004272.

30 Heys SD, Sarkar T, Hutcheon AW: Primary docetaxel chemotherapy in patients with breast cancer: impact on response and survival. Breast Cancer Res Treat 2005;90:169-85. 